Essay

\title{
The great political and economic changes in the world after the drastic changes in eastern Europe: Why did China stand out in the turbulent world?
}

\author{
Haoxuan $Y \mathbf{u}^{1,2, *}$ \\ ${ }^{1}$ School of Resources and Safety Engineering, Central South University, Changsha, Hunan Province, China \\ ${ }^{2}$ Institute of Electrical and Electronics Engineers, USA \\ *Correspondence: yuhaoxuan@csu.edu.cn
}

\begin{abstract}
This paper analyzes the political and economic changes in the world after the drastic changes in eastern Europe, starting with Chinese President Xi Jinping's viewpoint "the biggest change in a century". Also, the new international situation and new development in the post-epidemic as well as the development path and direction of China in the post-epidemicera are expected.
\end{abstract}

Keywords: World structure, Politics and economics, Reform and development.

\section{Introduction}

Since the end of the World War II in 1945, the international political pattern has been gradually replaced by the Yalta System, in which the United States and the Soviet Union are the center of the whole world, and the Socialist and Capitalist camps form a confrontation and a Cold War was emerged. The international economic form is the confrontation between the market economic system of the United States after the "New Deal" and the backward Stalinism planned economy of the Soviet Union. And, The international situation is called "polarized".

But since the founding ceremony of the People's Republic of China of 1949, the countries represented by China have grown rapidly, leading the world in a multi-polar direction. During the Cold War, the Soviet Union gradually showed its declining trend, and the drastic changed in eastern Europe and the collapse of the Soviet Union occurred at the end of the 20th century, which declared the end of the Cold War. Since then, the world has changed dramatically, as a prelude to the great political and economic changes in the world.

\section{Background}

At the Central Foreign Affairs Working Conference of China held in Beijing from June 22 to 23,2018, Xi said the world was in "the biggest change in a century" and that another great opportunity would be presented for the great rejuvenation of the Chinese nation. While at the 1962 Meeting of 7,000 people, President Mao Zedong also predicted that China could build the world's most powerful modern socialist state in 50 to 100 years.

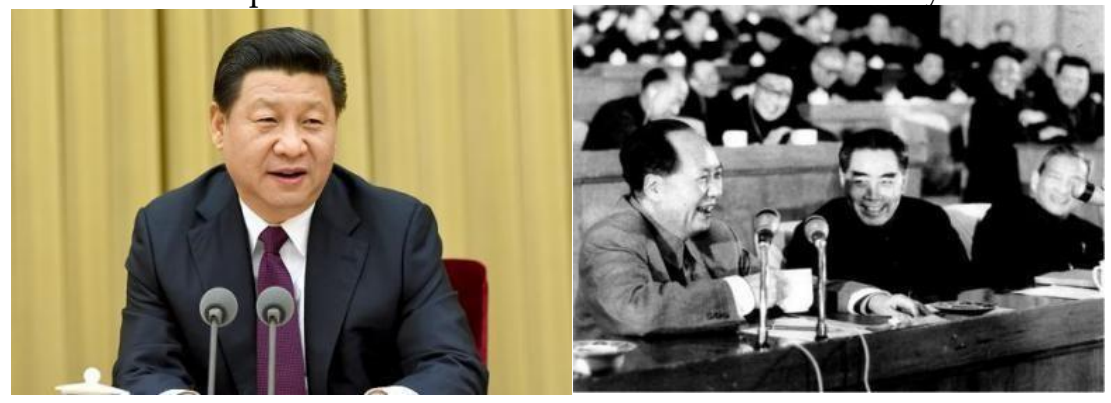

Figure 1. and Figure 2. The Central Foreign Affairs Working Conference and the Meeting of 7,000 people.

Indeed, since the 20th century, China has moved to the center of the world stage with an overwhelming momentum and become an indispensable and important member of the world: In the year 2020 when the world was plagued by the coronavirus, China, as the initiator, pushed all countries to participate in the building of a community of shared 
future for mankind. China's international status in the world has gradually improved, and its voice in the world has gradually become larger.

At the same time, with China's economic development since the reform and opening up, China has gradually become the world's first manufacturing country and the first commodity trading country. What is more surprising is that in 1978 China's contribution to world economic growth was less than $3 \%$, and by the beginning of 2020 it had reached around $30 \%$, in 1978 China's share of world GDP was only $1.74 \%$, by 2020 it will be more than $16 \%$.

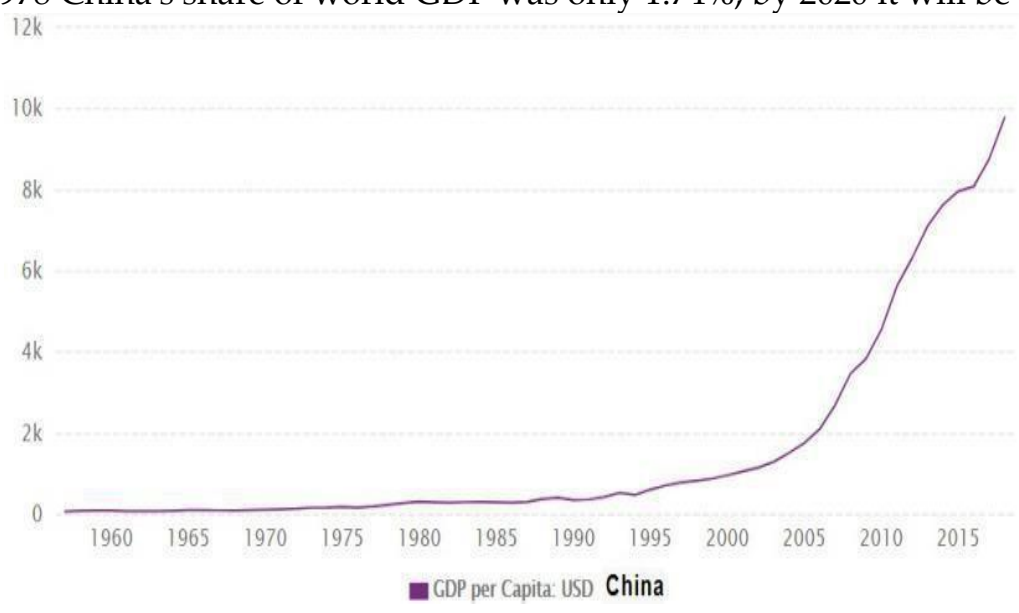

Figure 3. China's annual GDP growth chart, until 2018.

Much has changed in recent years, not just in China, but around the world. For example, Russia, known as China's "brother country", proposed in 2018 to join China's the "Belt and Road" and to link up with the Eurasian Economic Union to build the "China-Russia-Mongolia Economic Corridor Belt" which aims to promote regional economic integration, with emphasis on industrial, commercial and handicraft cooperation and mutual assistance. This is certainly a big opportunity for Russia, and Russia has rightly seized the opportunity, with a focus on Eastern Siberia development.

This new era of "the biggest change in a century" is the best of times, is also the worst of times. There are both potential crisis and opportunities for the "Challengers".

China seems to be the fastest growing country in the 21st century, from joining the World Trade Organization to hosting the 2008 Beijing Olympics, from the realization of manned space flight to the maturity of satellite technology, from GDP ranking first in the world to Huawei's mastery of 5G technology.

China's abilities to challenge this "the biggest change in a century" has much to do with the efforts and good decisions the Communist Party has made since the 1960s:

- At the First Session of the Third National People's Congress in 1964, Premier Zhou Enlai summed up president Mao Zedong's long-term strategic vision of socialist modernization and proposed a "Four Modernizations" strategy, that is, the modernization of agriculture, industry, national defense, science and technology, is China's rapid economic development, and therefore inspired the Chinese people's aspirations to establish a foothold in the world.

- After World War II, Vice President Deng Xiaoping pointed out clearly at the UN General Assembly in 1974 that the current international situation has undergone a sharp polarization, which has established China's strategic position as a "Third World" country.

- From December 1978, Vice President Deng Xiaoping, as the chief architect, opened the prelude of the reform and opening up of new China. Through the reform and opening up, China's economy was greatly developed and its international influence rose, and reform and opening up have provided powerful guarantee for China's modernization construction. 

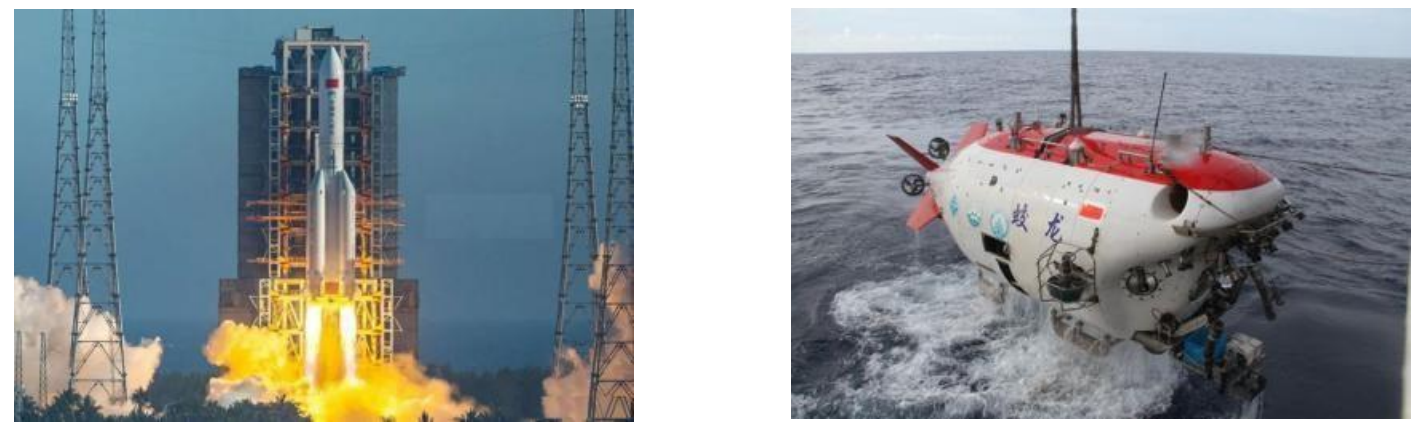

Figure 4. and Figure 5. The Long March 5B and The Jiaolong.

After decades of ups and downs, China has again faced a new round of opportunities and challenges, and the great rejuvenation strategy of the Chinese Nation is expected to be further implemented under this situation. For China, there will be another period of significant political, economic and global change.

\section{Analysis}

The great changes of world GDP pattern, industrial pattern, science and technology pattern, world trade pattern and world modernization can be traced back to the middle and late 20th century. As early as the middle and late 20th century, the world's great changes have already shown the signs of budding.

Since the 1940s, the "Third Technological Revolution" led by Einstein and Neumann pushed the world's industrialization to a new climax. The United States was clearly the greatest beneficiary of the "Third Technological Revolution" sizing the opportunity to fully develop new technologies such as atomic energy, computer, space technology, and bioengineering. The advent of the computer, in particular, helped to elevate American technology to a higher level. To America's rivals, the Soviet Union's progress in the "Third Technological Revolution" was sickening and a potential factor in the upheaval in eastern Europe. The socialist system of the Soviet Union was inherently limited, and the Soviet economy grew very slowly without the support of a sound and advanced market economy. In the "Third Technological Revolution", the Soviet Union developed in a single direction, focusing on the development of atomic energy and nuclear industry, emphasizing national defense and strengthening the country, and neglecting the construction of infrastructure and the development of other industries. As a result, the Soviet Union has become the "thick-armed", even until now, Russia's light industry as well as handicrafts are still mostly dependent on imports.

When the Communist Party came to power in eastern Europe, they all copied Stalin's model of socialist development. However, the Stalin's model of socialist development could not overcome its inherent problems, and the Soviet Union was aware of its own problems and was eager for a change, but it failed in the path of reform, which was the direct cause of the collapse of the Soviet Union.

On the American side, economic growth has been booming since the "New Deal" of the market economy in 1933. At the same time, promoted by the capitalist system of the United States, the country's advanced science and technology has made rapid progress and development. Therefore, under the joint effect of the internal contradictions of the Soviet Union and the conflicts with the United States, great changes have taken place in eastern Europe.

Around 1989, the eight socialist countries in eastern Europe successively denied the leadership of the Communist Party and the socialist system, transformed to the Western system and borrowed the development direction of the Capitalist Society from the United States. All revealed the fall of the Berlin Wall, the eventual annexation of East Germany to West Germany, the dissolution of the Socialist Federal Republic of Yugoslavia and the Czechoslovak Federation, the demise of the eight Eastern European states, and the end of the Cold War. Then, in 1991, the Soviet Union collapsed. Since then, the socialist countries in Eastern Europe have all turned to the Western political and economic system, learning from the Western capitalist system represented by the United States and the advanced market economic system.

The world structure changed:

- The pattern of "Only Super Power and Multi-Great Power" in the world has basically taken shape, and the world situation is turbulent and unstable. The former socialist countries in eastern Europe, represented by the Russian Federation, have made remarkable progresses in their transition to the Western system. Undoubtedly, the capitalist system was regarded as the "right path" at that time, the political systems of more countries were leaning towards the development of capitalist political systems. 
- In 1993, the European Union was officially born. The establishment of the European Union has promoted the formation of European integration and the development of European economic. In addition, the establishment of the European Union has provided a model for the development of regional groups. The world economy is beginning to move towards regional grouping, the examples include the North American Free Trade Agreement, the CIS Economic Union and the Black Sea Economic Cooperation Zone.

- The development of the countries represented by China has pushed the world pattern towards multi-polarization, and the rise of China has also proved that the socialist system is advanced to some extent.

\section{Discussion}

Why did China stand out in a turbulent world?

The founding of New China in 1949 marked the beginning of the Chinese Nation to stand on the world stage, laying the foundation for China to win its due position in the world.

Reform and opening to the outside world contributed to the strengthening of the Comprehensive National Power, which was the main reason for China's standing on the world stage, and the basic guarantee for the prosperity of the Socialist System with Chinese characteristics. In addition to the known factors, this part will lead "why China could stand in the turbulent world pattern? " to a new direction of thinking from one of the angles to discuss the internal and external causes of the rise of China's international influence in modern times.

\subsection{Internal cause: A new round of reform in China}

Since the end of the 20th century, China began to carry out a new round of reform movement.

Taking the reform of China's medical and health system as an example: The process of the reform of China's medical and health system is from the initial introduction of advanced medical facilities, medicines and medical technology, which improved the level of medical devices and medical technology in China, to the reform of the social medical insurance system, politically, the relevant laws and regulations were improved, and the amount of medical reimbursement increased, thus providing a basic guarantee for the health of the people. Finally, through Ideological Education Enlightenment, through the publicity of medical insurance and social security, people were urged to seek medical treatment immediately when they fell ill not worrying about medical expenses.

At present, as far as health care reform is concerned, great breakthroughs have been made in the stage of the "Ideological Education Enlightenment " but many people still hold the old concepts, such as "it's okay to be sick, just endure it" , or "the hospital is all for money, if you are sick just lying on the bed yourself for a few days to be good" .

For another example, since the end of the 20th century, most of China's enterprise system reform has carried out, from the upgrading of equipment, and to the reform of the system, finally to the enlightenment of the thinking of enterprise personnel. In all, this kind of reform in China is attributed to the continuous updating of material conditions, system basis and new enlightenment ideas. As well, the reform of China's political system also follows the same form.

It is precisely because in the course of its development, China has been constantly trying to correct mistakes, from the state socialist system down to enterprises and individuals, carrying out corresponding reforms with high standards and strict requirements, and making standardized planning for the country's development, to realize the development of Chinese characteristic socialism in the new era and the magnificent blueprint.

\subsection{External cause: China's development policy of international economic cooperation with other countries}

Since the 21st century, the scene of prosperity in the world appeared:

- The rapid development of the world globalization.

- The economic, political and cultural integration between countries.

- Harmonious development, cooperation and progress instead of the state-to-state infighting.

China has consistently followed and advocated the path of peaceful development since the "Five Principles of Peaceful Coexistence" was put forward, particularly in September 2013, when President Xi Jinping first proposed the New Silk Road Economic Belt, and in the following decades, step by step, China has been improving the "Belt and Road" initiative. 
The "Belt and Road" and other international economic development cooperation initiatives not only promote economic and trade exchanges and economic development among countries, but also promote China's diplomacy. It's a good time to increase its international influence for China:

- In the context of the "Belt and Road", China has taken the initiative to offer foreign aid, providing many resources, equipment and technical assistance to countries such as Iran.

- Russia, China's "brother country" mentioned above, has seized the opportunity of the "Belt and Road" and focused on planning the development of the frigid regions of the Eastern Siberia region, in particular, the exploitation of the mineral resources of the Eastern Siberia.

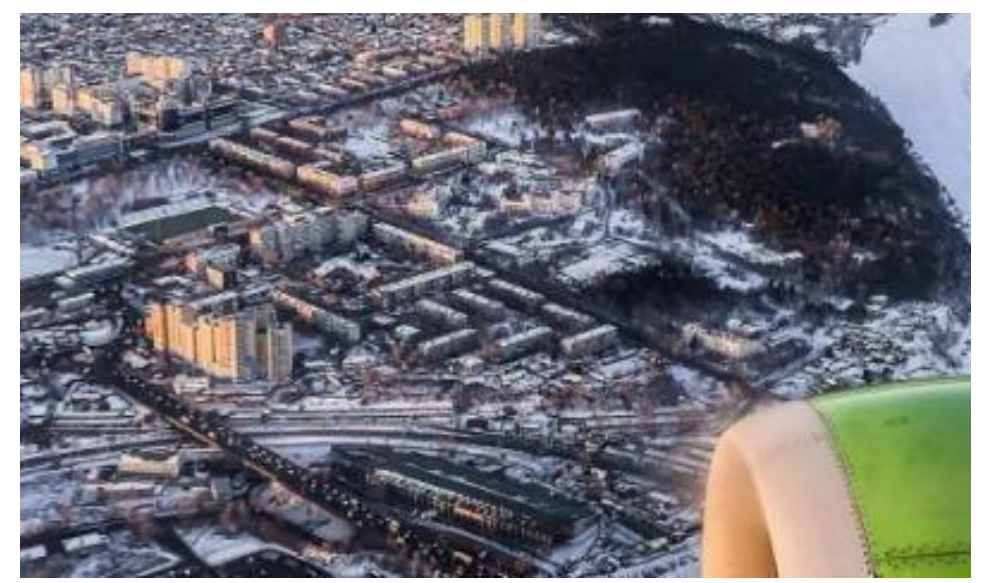

Figure 6. The Irkutsk of Russian Eastern Siberia.

The promotion of economic development such as the "Belt and Road" is conducive to the development of economic cooperation between Asia, Europe, Africa and other countries in the world, as well as to the stability of political and military peace in the region. At the same time, it also promotes China's diplomacy, it shows the unique style of the Chinese nation before the world, which revealed that The Chinese Dragon standing in the forest of the nations of the world.

\section{Prospective}

\subsection{Changes in the world pattern in the post-epidemic era}

The epidemic will undoubtedly have a far-reaching impact on the world landscape, so the world landscape in the post-epidemic era is bound to change significantly:

- The epidemic is holding back the global economy but is not expected to return to the pre-epidemic prosperity for three to five years after the end of the epidemic.

- The epidemic is a major test for different institution and ideologies, prompting each to reflect and adjust, and to make up for the weaknesses and shortcomings in time, thus promoting exchanges and mutual learning among different civilizations.

- The epidemic is not over yet, countries around the world still need to prepare for the epidemic.

- The epidemic will bind the fate of all mankind together, the "Community of human destiny" will be put on the agenda.

\subsection{How can China seize the opportunity in the post-epidemic era?}

The United States, despite the devastation caused by the epidemic, is still one of the most important factors in the international situation, so the relationship between China and the United States remains crucial. On November 25,2020, Chinese President Xi Jinping telephoned Joseph Biden to congratulate him on his election as president of the United States, which is a signal that China is willing to co exist and develop in concert with the United States, it is also a signal of a rapprochement and normalization between China and the United States. Although there will be no sub- 
stantial changes in sino-us relations after Biden takes office, and the frictions and contradictions between China and the US will not disappear overnight, after the epidemic, for China and the US, the situation of One world, Two markets and Two systems will not change. China and the United States are two of the most important countries in world, and there undoubtedly will be continued economic trade between the two markets.

Therefore, if China wants to seize the opportunity in the post-epidemic era, first and foremost, it should handle the relations between China and the United States, handle the relations with Taiwan, handle the good-neighborly and friendly relations with China's neighboring countries in the political field, in the economic and trade fields. The Trade with the United States should be strengthened to promote the further development of economic strategies such as the "Belt and Road" and globalization.

On the other hand, China, as the main sponsor of the construction of the "Community of human destiny", should strengthen exchanges and contacts with other countries while preparing for the prevention and control of the epidemic. In the process of global epidemic prevention and control in 2020, China will take the lead in setting a good example, and under the leadership of the Communist Party of China, the whole country will work together to combat the epidemic, all of these provided the reference for other countries in the world, and the outstanding contribution of China to the development of new coronavirus vaccine enhanced China's influence in the world.

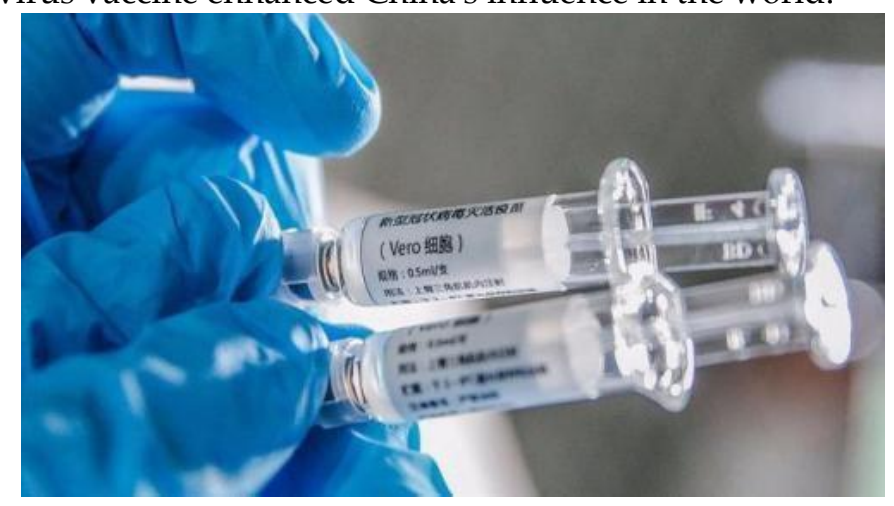

Figure 7. A new inactivated coronavirus vaccine developed by a Chinese team.

Secondly, the Communist Party of China should lead the people of the whole country to unswervingly follow the path of Socialist development with Chinese characteristics, constantly push forward the reform of the system and make further progress towards socialist modernization. In the post-epidemic era, there is no doubt that the world situation will become more turbulent and the people of all countries will become more upset. Therefore, we Chinese people should follow the leadership of the Communist Party of China and eliminate fear and anxiety, to devote ourselves to the development and construction of a modern socialist country, to make continuous efforts for the Chinese dream, and to challenge the "the biggest change in a century".

\section{Funding:}

The authors thank the financial supports from the National Natural Science Foundation of China (51804337).

\section{Authors' Contribution:}

Haoxuan Yu- Conceptualization / Writing - original draft / Writing - review \& editing.

\section{Acknowledgment:}

Special thanks to the editors for long-term guidance to authors.

Thanks to MDPI.

The authors thank the financial supports from the National Natural Science Foundation of China (51804337).

\section{Conflicts of Interest:}

The authors declare no conflict of interest.

\section{References}

1. Xi, J. 1., (习近平). (2014). Xi jinping: The governance of china (1st ed.). Foreign Languages Press. 
2. FERDINAND, P. (2016). Westward ho-the china dream and 'one belt, one road': Chinese foreign policy under xi jinping. International Affairs (London), 92(4), 941-957. https://doi.org/10.1111/1468-2346.12660

3. 3.1. glorifying xi jinping for his leadership in fighting the virus. (2020). Modern China Studies, 27(2), 172-181.

4. Pei, M. (2017). assessing xi jinping's anti-corruption fight: Views from five scholars. Modern China Studies, $24(2), 5$.

5. Rencz, F., Gulácsi, L., Drummond, M., Golicki, D., Rupel, V. P., Simon, J., Stolk, E. A., Brodszky, V., Baji, P., Závada, J., Petrova, G., Rotar, A., \& Péntek, M. (2016). EQ-5D in central and eastern europe: 2000-2015. Quality of Life Research, 25(11), 2693-2710. https://doi.org/10.1007/s11136-016-1375-6

6. Golinelli, R., \& Parigi, G. (2014). Tracking world trade and GDP in real time. International Journal of Forecasting, 30(4), 847-862. https://doi.org/10.1016/j.ijforecast.2014.01.008

7. Hedlund-de Witt, A. (2014). Rethinking sustainable development: Considering how different worldviews envision "Development" and "Quality of life". Sustainability (Basel, Switzerland), 6(11), 8310-8328. https://doi.org/10.3390/su6118310

8. Valdiserri, R. O. (2020). Epidemic: A narrative matters poem about HIV/AIDS; an epidemic not over but often forgotten. Health Affairs, 39(4), 716-716. https://doi.org/10.1377/hlthaff.2020.00057

9. Volkow, N. D., Frieden, T. R., Hyde, P. S., \& Cha, S. S. (2014). Medication-assisted therapies - tackling the opioid-overdose epidemic. The New England Journal of Medicine, 370(22), 2063-2066. https://doi.org/10.1056/NEJMp1402780

10. Vengušt G, Žele Vengušt D, Toplak I, Rihtarič D, Kuhar U. Post-epidemic investigation of Schmallenberg virus in wild ruminants in Slovenia. Transboundary and emerging diseases. 2020;67:1708-1715. 